\title{
船船およよび海洋構造物の防食*
}

\author{
森 \\ 稔**
}

\section{Corrosion and Protection of Marine Structures}

by

\section{Minoru MORI}

(Technical Research Laboratory, Kawasaki Heavy Industry Co., Ltd., Akashi)

最近の船舶の傾向として, タンカの大型化が一段落 し,ケミカル・タンカ, プロダクト・キャリア, LPG 船, LNG 船などの特殊船の建造が増加しつつある.

一方海洋構造物としては, 石油をはじめ各種の海洋 資源開発を目的とした作業台, プラットフォーム, 貯 蔵タンク，パイプラインや，国土開発を目的とした海 底トンネル, ケーソン, 海上長大橋, 港湾設備および 発電プラントが建設され，海洋環境にさらされている。

これらの構造物の強度メンバーには, 主として鉄鋼 材料が使用されているが; 腐食の問題は軽視すること がでさない，一般に海洋構造物机かぎらず，さびに関 する損失は非常に大きく, 米国だけでも年間千万ドル は下らないといわれている。これを腐食による年間損 害補償費に扣きかえてみると更に大きな金額となり， 米国では70８0億ドル，英国では 6 億ポンド，カナダ では1億ポンドになると報告されている。船舶関す る損失例によると, 年間鋼材損耗量は $500 \sim 750 \mathrm{~g} / \mathrm{m}^{2}$ であり,これを 5 万トン級のばら積船にあてはめて計 算すると，年間損耗量として約 $40000 \mathrm{~kg}$, 金額に換 算して約 6 万クローネの損失になる.

このような損失の背景には, 海洋における腐食環境 があり, 大別すると大気, 飛沫带, 潮干満帯, 海中 （浅海，深海）㘧よび海底土中に分けられる。これら の環境では, それぞれ腐食条件が異なるため, 発生す る腐食現象にもかなりのちがいが認められるが, 一般 には潮干満帯の腐食速度が大であるとされている。し たがって，このよらな海洋環境から構造物を保護する ためには，多数の防食法の中から最孔効果のある方法 を見いだす努力が必要である。このために各種の研究， 試行がなされているが, 最近はデジタル・データ・レ コーダが利用されるにいたり，腐食の研究分野におけ る測定と記録, データの統計解析のほかに図表まで行

* 原稿受理 昭和51年 4 月 22 日

** 正会員川崎重工業(株)技術研究所 明石市川崎町
われるよらになっだ. しかし, 一方では防食材料の選 択あるいは施工に関して規制が設けられたため, 従来 の方法がそのままでは利用できない場合があり，その 対策に苦心する時代となった.

本稿では，最近の文献の中から実績例に重点を和い て紹介し，各位の参考に供したい。

\section{1 船舶の防食}

\section{$1 \cdot 1$ 船舶に用いる最近の塗料について}

船舶に用いる塗料に対する船主の期待は, 船体の防 食と船速孛低下させないための防污であうう，船船塗 料の種類は非常に多いが, 塗装仕様の決定は, 価格, 品質はもとより従来からの実績を参考にすることが多

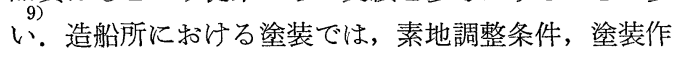
業条件, 塗装設備, 塗装工程, 作業者の技術, 検査な ぞが問題になるが，現在の技術を有効に利用す犵ば， 船舶の防食の分野で, 年間 5500 ポンドが節約できる といわれている.

船舶の塗料扰よび塗装費について Mock は，25万 トン級のスーペータンカの場合約 500000 ドル（イ= シャル・コスト）と述べている。一般に防食のための コストは, イニシャル・コストだけで価值判断されが ちであるが，実際にはメンテナンス・コストを含めた トータル・コストで判断しなければならない。とくに 最近は, 入渠間隔の延長が行われ, 塗替周期の長いす ぐれた防食塗装の要求が強く, また塗膜の長期品質保 証といらことから，塗料メーカは塗料だけ売るのでは なく，施工を含めて防食塗膜を売るという，いわゆる 責任施工制度が広まりつつあり, 品質保証と塗料によ る防食システムの収益性について注意がはらわれるよ らになってきた.

このよらな背景のもとに, 最近の船舶用塗料は重防 食, 厚膜型化の検討が進んできた，その代表的なもの を選び以下に紹介する.

(1) 塩化ゴム塗料 
塩化ゴム塗料は，さび止叙料（1号塗料）として， この10年間めざましく進歩した．この塗料の荷姿は 1 液型で, その塗膜は透水性が低く耐薬品性, 耐候性に すぐれ， 1 回の塗装で $3 \sim 6$ ミルの厚さとなる. 本塗 料は再塗装が容易で, しか子塗装時の温度の影響を受 けにくく実用上の利点が大きい，塗りか觉周期は, 通 常の塗料の 1 年に対し約 4 年といわれている。 とくに 北欧での使用実績が多く, 我が国の船舶の外板塗装の 主流でもある。

(2) エポキシ塗料

エポキシ塗料は, 塩化ゴム塗料とちがい, 荷姿は 2 液型で主剤と硬化剂を混合して用いる塗料であり, 塗 膜の耐薬品性は非常にすぐれている. しかし, 乾燥工 程で 1 週間 $10 \%$ 以上保持することが必要であり, 寒地 では不利な点もある. 塗膜の性能としては, 耐純水性 および耐候性に問題があり，また乾燥工程で溶剤蒸発 により塗膜の厚さの目減りがある. しかし，無溶剤化 すれば, 先に述べた目減りの現象はなくなり, 塗装環 境の毒性, 爆発性を改善しながら, 厚膜化ができる。 ただし，この場合主剤と硬化剤の反応速度が大となり， 従来の塗装機では叙装しにくくなるので 2 成分をちが ったノズルから同時に吹付ける方法などを採用すれば 実用化が可能である。本叙料は船体外板のほかにタン ク（ケミカルタンカ, プロダクトキャリア）への利用 が增加するものと思われる。

(3) タール・エポキシ塗料

タール・エポキシ塗料は, 先に述べたエポキシ塗料 にタール成分（コールタール，ピッチ，膨潤炭など） を混合したもので, 荷姿および塗膜になるまでの乾燥 工程は, エポキシ塗料によくにている. しかし, ター ル成分を加えてあるため, 通常の塗料比比較して1回 塗装あたりの塗付量が大きく, 厚膜型の塗料であるこ とが特徵である. 主として, タンカのカーゴオイルタ ンク，バラストタンクおよび外板など広い面積に使用 されている.

(4) ビニル塗料

ビニル塗料は, 塩化ゴム塗料と同様 1 液型で, 同塗 料より更に古くから用いられて招り, 耐水性, 耐候性 にすぐれている. 本塗料は, 再塗装は容易であるが, 1 回塗装あたりの塗付量が少ないため塗装回数の多い ことが欠点である. しかし，最近は 1 回塗装あたり 125 ミクロンメータ厚さのものも開発されているので, 塗装法を考案すれば実用化が可能となる.

使用実績としては，米国では海軍に多く，日本では 小型船舶によく用いられている.

(5) ポリウレタン塗料

ポリウレタン塗料は, エポキシ塗料と同様の荷姿で 主郕と硬化剂を混合して用いるが，塗膜に光沢があり
色彩としてすぐれた外観が得られるという特徴がある。 我が国では船舶に用いられた例は比較的少ないが, Kubitza はポリウレタン塗料の用途として, タンクに はトリレンジイソシアネート/トリメチロールプロパ 配合品を, 甲板には無溶剤品を, 水中の使用にはタ 一ル配合品の使用例をあげて説明している.

(6) 塗料の無溶剤化

無溶剂塗料は, 1 回あたりの塗付量を増して厚膜化 ができるため，塗装回数を節減できるといら利点の注 かに, 塗装中括よび乾燥工程中の溶剤蒸発を扣さえる ことができるので，公害対策としても期待がもてる塗 料である. しかし, 高粘度であるため新規の塗装設備 および高度の塗装技術が要求されることも事実である. 叙料としてもレオロジ一的な性質や被塗物への付着性 などを改良すれば，船舶用塗料として今後広く使用さ れるものと期待される.

\section{$1 \cdot 2$ 防污塗料について}

船底に海洋生物が付着し, 船速を低下させるという 事実は, 紀元前 400 年頃から認識があり, その後いる いちな対策がとられてきたが，1625年銅化合物が防污 顔料として有効であることがわかって以来, 現在まで 利用され続けている。最近では, 防污の添治船体の 摩擦抵抗を減少させる塗料の研究が行われ, 航行試験, いかだ試験, 流出機構の解明が行われている.

防污剤の防污効果を明らかにするには溶出機構の解 明が必要で, 亜酸化銅の溶出機構については, 航走条 件および静止（停泊）時などの銅イオンの溶出速度に ついての研究がある.

しかし, 近年防污剤に各種の有機物が利用されはじ め，有機すず，有機鉛などが開発された。.この場合の 防污効果の判定には, 実験室で飼育したフジッボを使 って効果の確垫が行われ, 生物学的なアプローチが導 入されだ.この方法は, 防污剤単独の能力判定には有 効であるから, 塗料化された場合の塗膜の防污効果判 定への応用が期待される. また, 船体の摩擦抵抗低下 については, 流体への有機重合体の添加が有効ともい われ, 酸化ポリエチレンの場合, 添加濃度 $7.5 \times 10^{-4}$ \%で抵抗の減少は $45 \%$ に達するという報告がある.

また, 船舶の巨大化とドック不足に関連して, 水中 補修（ブラシ・ボート）も試みられている. この他に 摩擦抵抗の減少方法として, フレーク・ガラス・ポリ エステルの利用の紹介もあり，30〜35ミルの厚さで 5 年の寿命があり，ビニル系防污塗料と組合せて使用す れば，入渠間隔は 4 年でよいといわれている.

\section{$1 \cdot 3$ タンク用塗料}

タンクの内側は, 船体強度の補強のため縱, 横の助 骨, 隔壁などの骨組構造となっているため塗装面積は 非常に大きく, 通常外板の 3 倍程度といわれている. 
今， 7 万 $\mathrm{m}^{3}$ のタンクを例にとるとその塗装面積柱約 18 万 $\mathrm{m}^{2}$ あり塗装コストは 710 万クローネを必要とす る. バラストタンク用塗料としては各種のものがある が，一般にはタールエポキシ塗料の使用実績が多く， 我が国で最初にコロージョン・コントロールを適用し た千じん丸（12万トン）にもこの塗料が適用されてい る.タールエポキシ塗料に関する研究は多くあり，我 が国でもワン・コート・システム・タールエポキシ塗 料（乾燥膜厚として 200 ミクロンメータ以上, 硬化乾 燥時間 $24 \mathrm{hr}$ ) が開発され，造船塗装工程の短縮に寄 与している. タールエポキシ塗料の特徴は, チクソト ロピックな性質を活用して，ハイビルド化（厚膜化） が可能なことで, その特徵をいかした製品は多い.

また，有機けい酸亜鉛塗料（比重 3.3 , 乾燥膜厚に して75ミクロンメータ）は，1955年頃からタンカの荷 油タンクに使用され始めた. この塗料の防食機能の特 徵は, カソード防食作用といわれ，作業面では毒性， 臭気がないことである、初期コストは高いが，ドック 期間を長くとれるので，10年間で 6.7 万ドルの節約が 可能といわれている. この塗料はばら積船にも利用さ れている.

この他に，特殊な例として，素地調整を必要としな い浮遊塗装法（1000１500ミクロンメータ），ケミカ ルタンクの被覆としてポリエチレンの被覆，鉱石船を 対象としたポリサルファイド塗料の塗装などがある.

\section{$1 \cdot 4$ 陰極防食法}

1824年 Davyによって陰極防食法が見いだされて以 来, 同法は船舶の防食のために約 150 年間利用され続 けている.

現在は，ぎ性陽極を用いる流電陽極法のほかに外部 電源法も船舶に利用されている.

流電陽極法では，当初マグネシウム陽極がよく用い られたが，1950年代に亜鉛陽極にかわり，1960年代に はアルミニウム合金陽極が加わった. 船体外板の場合 は, 防食電流密度の均一分布を考虑した取付位置の検 討と船体抵抗の増大にならないよらな形状の研究が行 われ現在にいたっている. 流電陽極法は外板の他にバ ラストタンクの防食にも多く利用され，現在は主とし てアルミ合金陽極が用いられている.

流電陽極を船体外板に使用した場合の経済的な利点 として, Taylor らは駆逐艦の場合入渠 1 回またり 1 万 〜 万ドルのメンテナンス・コストが節約になると報 告している. バラストタンクの場合は外板とちがい, 温度, タンクの洗浄状態, はり込み海水の污染度, 空 倉のインターバルなどが問題となる.

外部電源方式の防食例として が最初といわれているが, 適用された電流密度は, $100 \mathrm{~mA} / \mathrm{m}^{2}$ といわれている.
院極防食法は，上記のような外板およびタンクのほ かに，銅合金の脱亜鉛防止，キャビテーション・エロ ージョンの減少, $\mathrm{Cr}-\mathrm{Ni}$ 鋼の孔食の防止, すきま腐食 の防止および腐食疲学の防止などにも広く応用されて いる.

陰極防食法は，塗膜と併用することが多いが，この 場合, 過防食になると塗膜の破壞（アルカリによる損 傷）が起るので, 両者の適合性について注意する必要 があり，ビニル塗膜およびタールエポキシ塗膜が適当 であるといわれている.

\section{$1 \cdot 5$ その他の話題}

塗膜の品質は, 塗装作業条件とくに素地調整グレー ドの程度と密接な関係がある. 船舶の建造とくに超大 型船の場合, 塗装のための専門工場をもつようになり, 素地調整, 空調, 除じんなどの装置を備え, 最適条件 で塗装作業を行って塗膜の品質向上に努めている.

塗装機については, 現在ひろく利用されているェア レス・スプレイ装置のほかに，高粘度塗料のための塗 装機（加熱ヒータ付圧送スプレイ）の開発， ガラス緎 維入りポリエステル樹脂のスプレイ技術の開発があげ られる。

ライニングの適用例としては，鋼管内面に対するエ ポキシ樹脂, 塩化ビニル樹脂执よびポリエチレン樹脂 の利用があり，加工法としては高周波を利用した管の 曲げ加工と樹脂ライニングがあげられる。

素地調整法としては, 通常ブラスト処理（サンド, グリット，ショットなど），パワーッール処理（ディ スクサンダー, パワーブラシなど）がよく利用される が，修繥船へのインヒビタの利用例として，高圧放水 （ウェットブラスト）による船体表面清浄の場合に， 処理後の発せい防止のために水にポリリン酸, 覀硝酸 ソーダを添加することが行われている.

特殊な例としては, カナダの修繥船で塗装下地とし て船体に亜鉛のフレームスプレイを利用したといら報 告もある。

水中作業については，ドライドックを使用しないで 船体の水線下を検查する技術に関する報告がめり, 水 中カメラを利用した水中作業法などは船体の水中保守 を検討する場合の参考となる。

\section{2 橋梁の防 食}

最近の橋梁は, 海洋環境に架設されることが多くな り, 海洋構造物の中の一つの大きな分野となっている. したがって, 最近は橋梁が架設される場所や位置の環 境条件と鋼材の腐食に関する研究や調查の報文が幾つ かあり，また防食についても塗料沶よび施工（塗装機， 足場，機械化など）に関する報告書や，本四連絡橋関 係の試験調查報告がある。

これらの報告によれば，塗装下地としてジンクリッ 
チペイントまたは金属亜鉛被覆の施工を推奖している が，一方このような塗装下地に対しては現地で中，上 塗りを施工する場合には, 叙料の種類によっては付着 性が充分でないという報告もあり，実橋の塗装仕様の 選定と施工管理については充分検討する必要がある.

\section{$2 \cdot 1$ さび止塗料}

橋梁のさび止塗料としては, 酸化鉄さび止塗料, 鉛 丹さび止塗料, クロム酸系統のさび止塗料が用いられ てきた.クロム酸亜鉛顔料の防せい作用は, 従来はク ロム酸イオンによる金属表面の不働態化作用といわれ ていたが, Meyerはクロム酸亜鉛錯体アニオンによる 防せい作用を主張している. 金属鉛の使用を検討した例もあり，この場合金属鉛が 表面で空気や水と接触して酸化し, 内部にこれらの腐 食因子が到達するのを妨害して防食作用を行らといわ れている.

最近は, 従来のさび止塗料と少しちがったジンクダ ストペイント（鉛けけい酸亜鉛系プライマなど）や， MIO (マイカシアス・アイアンオキサイド） の利用が 行われるよらになった。

\section{$2 \cdot 2$ さび面塗料}

従来のさび止塗料は，塗装前に金属表面のさびや污 れを充分に除去した上で塗装することがたてまえであ った. しかし，近年さびの上へ直接塗装できる塗料の 開発が進行中であり，検討も行われている.この塗料 の特徵は，金属上に存在するさびと反応または浸透し て被膜を形成し, さびの進行をとめる安定化層を形成 することで，浸透剤としてはタンニン酸などがあり鉄 との錯体を形成するといわれている。現在開発された ものとしては，フェライト系顔料のさび変性能を利用 した塗料や，合成樹脂のビヒクルに浸透性をもたせ活 性顔料を配合したさび面塗料があげられる。これらの 塗料には，塗膜損傷部のさびを拉さ光，塗膜下へさび が浸入するのを防止する効果や，施工面では湿潤面へ
の塗装効果についての報告がある.

\section{$2 \cdot 3$ 橋梁塗装仕様例}

(1) 外国での例

外国での著名橋梁の塗装仕様例を表 I に示す．英国 では，亜鉛溶射施工面の上へ MIO 塗料を塗装する仕 様が多く，米国では無機質ジンクリッチプライマの下 塗りの上へ塩化ビニルまたはエポキシ樹脂塗料を塗装 する仕様が多い.いずれの場合も，イニシャル・コス トは高価であってもメンテナンス・コストの低廉な塗 装仕様が適用されている.

(2) 国内での例

我が国の橋梁の塗装仕様は，従来は油性鉛丹さび止 塗料の下塗りにフタル酸樹脂系の上塗り塗装仕様が多 かった.しかし，最近の鋼製長大橋では，次第に欧米 の影響を受けてメンテナンスのかからない塗装仕様へ と移行している.

耐候性鋼材を使用した例としては，四日市高架橋， 神戸大橋などがある. 前者の例では石油コンビナート に和ける亜硫酸ガス対策として, 上塗りに塩化ゴム塗 料が適用されている．後者の例では通行する自動車の 排気ガスと海塩粒子対策としてフェノール系 MIO 塗 料の中塗り, 塩化ゴム塗料の上塗り塗装が適用されて いる.

最近完工した関門橋（全長 $1068 \mathrm{~m}$, 中央径間 $716 \mathrm{~m}$, けた高さ61m, 使用鋼材重量 28000 トン）では, 補剛 けた全面に塗装下地として亜鉛メタリコンが施工され， 中塗りはフェ 塗料である. 海洋環境に長期間耐えることを目標に, このよらな塗装仕様が選ばれている.

\section{$2 \cdot 4$ その他の話題}

(1) ケーブルの防食

吊橋の場合, 主塔間に張られたケーブルからトラス を吊下げているので，ケーブルは橋の生命であると考 えてよい.このケーブルのワイヤに建設中ではあるが

表 I 著名外国橋梁の塗装実施例

\begin{tabular}{|c|c|c|c|c|c|c|c|}
\hline 橋梁 名 & \multicolumn{2}{|c|}{ 施工場所 } & 涩 & 系 & 塗替周期 & 架設環境 & 備 \\
\hline フォース道 路 橋 & 英 & 国 & \multicolumn{2}{|c|}{$\mathrm{Zn}$ 溶射 $-\mathrm{W} / \mathrm{P}-\mathrm{Z}$ C. さび止め-MIO 塗料 $\times 2$ 回 } & 6 年後良好 & 海上 & \multirow[b]{3}{*}{ 日本て組立後現地架钤 } \\
\hline セ バ 一 ン 橋 & 英 & 国 & 同 & 上 & 4 年後良好 & 海上 & \\
\hline オークランドハーバー橋 & \multicolumn{2}{|c|}{ ニュージ } & 同 & 上 & 2 年後良好 & 海上 & \\
\hline ラウシュウッド橋 & 英 & 国 & Z.R.P.× 2 回-Z.C.さび」 & $-\mathrm{MIO}$ 塗料 $\times 2$ 回 & 10年後良好 & 海上 & \\
\hline グインヒール橋 & 英 & 国 & $\mathrm{Zn}$ 溶射-W/P-Z.C さび」 & -MIO 棌料 $\times 2$ 回 & 10年後良好 & 海上 & \multirow{3}{*}{$\begin{array}{l}\text { 新設時は油性系 } \\
\text { 現地ブラスト後エアレ } \\
\text { ス鋫装 }\end{array}$} \\
\hline ゴールデンゲート橋 & 米 & 国 & 無機質 Z.R.P.-W/P-厚膜 & $\mathrm{V} \times 2$ 回 & 㳵 替 中 & 海浜 & \\
\hline サンマテオヘイワード橋 & 米 & 国 & 無機質 Z R.P. $-W / P-V$ & 止め-厚膜型 $V \times 2$ 回 & 洤替 中 & 海浜 & \\
\hline$=\geq-ホ ゚-卜$ 橋 & 米 & 国 & 無機質 Z.R P.-E さび止 & 苩膜型 $\mathrm{E} \times 2$ 回 & 塗 替 中 & 海浜 & 同 上 \\
\hline ジョージワシントン橋 & 米 & 国 & 伷性さひ止め× 2 回-A R. & 余-A R 上塗 & 4 年一 5 年 & 海兵 & \\
\hline
\end{tabular}

〔注〕 W/P: Wash Primer Z R P. Zinc Rich Prımer V. Vinyl. Chloride Resin Z.C.: Zinc Chromate MIO· Micaceous Iron Oxide A R. Alkyd Resin R. L. . Red Lead 
切れが発見されたという報告があり，その原因として 線引き加工中にできたワイヤの表面傷をあげている. この場合は, ワイヤの防食として亜鉛めっきで処理し たわけであるが，めっき中に表面傷から水素が浸透し， 水素ぜい性が起ったと報告をしている.

ケーブルは，通常炭素鋼，低合金鋼，ステンレス鋼 などが用いられ，一般には防食被覆が施されるが，U Sスチールの16年間のテスト結果から炭素鋼, 低合金 鋼には亜鉛, アルミニウム合金の被覆が有効であると いわれている.

ケーブルに対する防食処理としては，亜鉛めっきが 多く用いられていることも事実で, 我が国の最近の例 として関門橋のケーブルにも採用されている.

この他，塗膜による防食も行われているが，き裂が 入り易いので, 水分の浸透によって腐食が起るおそれ があるため, 米国からプラスチック・ラッピングの導 入が行われている. また，ケーブルの周囲をマイラ層 やガラス纎維で被覆し，アクリル系の樹脂でかためる という方法もある.

（2）亜鉛被覆による防食

橋梁本体を亜鉛被覆によって防食施工したという報 告もかなりあり, 英国では1930年代から溶融亜鉛めっ きの施工が行われている. この方法は, 架設時の損傷 に耐えるといらことでョーロッパでは実例が多い. 亜 鉛溶射の例としては, フランスの Porte de la Chapelle の鋼製陸橋（曲率 $1000 \mathrm{~m}$, 長さ484 48 , 幅 $35 \mathrm{~m}$ ) に 120 ミクロンメータの厚さで施工され， スコットラ ンドのフォースブリッジ（欧州で最大の吊橋 $1800 \mathrm{~m}$ ) の懸垂橋鋼材にも同様な方法によっ されている.これらは, いずれもメンテナンスフリー を目的としている.

(3) 高力ボルト接合部

高力ボルト接合部の表面は腐食し易いので, 亜鉛め っきによって防食した例があるが，接合部であるため 摩擦係数值については検討する必要がある。接合部の 滑り防止法としては, 表面を強く研摩してアセチレン 炎を $3 \mathrm{~m} / \mathrm{min}$ の速度で照射し，ブラシで清掃した後 高力ボルトをしめつける。

\section{(4) その他}

外国における耐候性鋼の利用例としては, ノース・ カロライナの道路橋があり, また橋の再塗装のための 表面清掃を対象としたブラスト作業車（5万 2 千ドル, デトロイト）の開発があり，機動力を発揮していると いわれる。

\section{3 海洋構造物の防食}

海洋構造物としては, 海底油田掘さく装置, 海上採 油装置, 工事用プラットフォーム, 港湾設備, ドック, 橋ぐい, 水中トンネル, 発電プラントなど多数のもの
があげられる。

防食法としては, 塗料, 塗装のほかに陰極防食, 金 属溶射，溶融亜鉛めっきなどがあげられる，したがっ て, 船舶や橋梁の防食と基本的には差はないが，それ なりの特徵は有している.

\section{$3 \cdot 1$ 塗料による防食}

海洋構造物を保護するため用いられる材料につい ては報文が幾つかあり，整理して代表的なるのをあげ ると, 合成樹脂としてはエポキシ, タールエポキシ, ふっ素化エポキシ, ポリウレタン, ふっ素化ポリウレ タン, ポリエチレン, シリコン, ブチルゴムおよび各 種のエマルジョン, 顔料としては酸化鉄, MIO, 亜鉛, ジンククロメート, 鉛, 亜酸化銅拉よび有機すずが利 用されている.これらの利用形態としては, 塗料, 含 浸剂，混和剤，パテなどがあげられるが，一般には塗 料として用いられる場合が多い.

最近の傾向としては, さび止効果を期待してジンク リッチペイント（けい酸亜鉛系）の利用が増加してい ること, 重防食とメンテナンスフリーのため厚膜塗装 (120〜160ミクロンメータ) が増加していること, 深 海においては特別な問題があるのではないかという疑 問と検查技術の検討（塗装回数の規定，作業の監視） などがあげられる，また，陰極防食法と併用する場合 の塗装仕様の選定についても検討の余地がある.

海洋構造物では, 一般に飛沫帯の腐食がはげしいと いわれているが, 橋脚の例ではネオプレンの被覆が行 われ，この場合は被塗物との付着性をよくするために 素地調整の仕上げの程度が重要である. 飛沫帯の防食 については他に幾つかの報告があるが，モネルメタル， オーステナイト鋼, 銅ニッケル合金などとゴムの被覆 の組合せの例や，耐候性鋼の利用（強度上必要な厚み にさび代を加党て設計する)，コンクリート巻， ター ルエポキシ塗料の塗装などが紹介されている.

乾湿交番になる潮干満帯では, エポキシ塗料, ビ二 ル塗料のような一般的な塗装のほかに, ガラス緎維で 補強したエポキシ・ポリアミド樹脂のパテ付けをした という例もある。

無機質のジンクリッチペイントが海洋構造物に多く 使われるよらになったのは，例えばドックのデッキ上 は作業時に鎖, 砂, 工具, 海水および機械油などで損 耗が起るので, 通常の有機被覆では約18か月で破壊さ れるが，無機質のジンクリッチペイントの場合は 3 年 以上の耐久性があることが認められたからである.

塗装費については，米国の石油掘削企業の例では， $0.0929 \mathrm{~m}^{2}$ あたりの平均塗装費は40〜80セント, 再塗 装までの平均期間は $3 \sim 10$ 年, $0.0929 \mathrm{~m}^{2}$ あたりの修 理費は 5〜35セントといわれている. 塗装による防食 の経済性については,イニシャル・コストだけでなく 
メンテナンス・コストを含めたいわゆるトータル・コ ストで比較する必要がある.

\section{$3 \cdot 2$ 陰極防食}

海水中に和ける鋼構造物の防食には, 船船の場合と 同様に㓌極防食法が有効であり, 幾つかの文献がある が，最近は自動電位制御のできる外部電源法の話題が 多い.

陰極防食を設計する場合，海水の状況（流速，温度， 污染), 電気抵抗值 (海水, 土中), 陽極材料の選定, 構造物の形状と取付位置, 迷走電流の影響などが重要 な問題である.たとえば，温度の影響についてはメキ シコ湾のプラットフォームのために設計した仕様が北 海で有効とは限らないし, 水深によっても流電陽極法 （浅海では有利）にするか外部電源法にするからがっ てくるので, 環境条件に適した設計が必要であふ.

陰極防食の効果については, 我が国の場合港湾にお ける鋼材の腐食速度は $0.03 \sim 0.3 \mathrm{~mm} /$ year (平均 0.13 $\mathrm{mm} /$ year) といわれているが，陰極防食法を採用すれ ば防食効果として $80 \sim 100 \%$ が期待できる. その他の 効果としては, 繰返し荷重のかかった海水中での疲労 に対する効果，海水中に和ける銅合金の脱合金の予防 効果，304抢よび316ステンレス鋼の海水中でのすきま 腐食の防止効果, 海洋生物の付着に起因した通気差電 池腐食による高級ステンレス鋼の孔食防止効果などが あげられる。

陰極防食法の問題点としては， $140 \mathrm{~kg} / \mathrm{mm}^{2}$ 以上の 強さの高張力鋼の場合, 陰極電流の供給によって鋼中 に水素が吸収されぜい化を起すといわれて拉り, この よらな場合の院極防食の採用は好ましくない. また， 塗装による防食を併用する場合, 塗膜にとって過防食 の状態になると劣化が起る. 例えば院極防食電位が $-1.10 \sim-1.50 \mathrm{~V}$ (銅一硫酸銅電池) の場合, ネオプレ ン, ビニル，コールタールエナメル，タールエポキシ， 変性フェノール, アスファルト被覆などは劣化しない が，鉛丹さび止塗料，アルミニウムペイントなどはは ゲしく劣化する.

\section{$3 \cdot 3$ 溶射および塗装}

海洋環境での防食法の一つとして溶射法の利用があ げられる.この方法が採用されるのは, 被防食面積が 比較的小さくて, しかも酎食性のほかに耐摩耗性が要 求されるような場合か, 非常に長期の防食システムの 素地としての場合である.

溶射方法としては, 金属粉末の溶射, 金属線の放電 爆発溶射 (耐熱, 耐摩耗性), 爆発溶射 (耐摩耗, 耐 食性)，線爆溶射（パイプ内面など）などの方法があ げられる，海洋構造物へ適用される材料としては，亜 鉛，アルミニウムなどが多いが，このほかに鉛，すず などの溶射があり，このような処理によって得られる
被覆は一般に多孔質といわれているので，この性質を 利用して油その他の潤滑剂を含浸させ，耐摩耗性をあ げることに利用されている。

溶射の実例としては, ニューヨークで摩耗した引船 の船尾軸を高クロムステンレス鋼でメタライジングし， そのあとを旋削研摩して仕上げることが行われ，この 方法を採用することにより，従来の方法では $4 \sim 5$ 週 間かかる修理期間を20時間で完了し，ドック費 200 ド ル/day の利益が得られたといわれている. 同様な例 として粉末溶射によるカムシャフトの補修があり, こ の方法では入熱を小さくおさえることができるため， シャフトにねじれが発生しないことの他に, 従来の方 法に比較して能率は 1.5 倍に, コストは半分に低減し たと報告している.このほかに小面積の施工例として， レーシング・ヨットのキールに, 76.2 152.4 ミクロ ンメータ厚みの亜鉛溶射を行い，その上をポリエステ ルで仕上げれば，滑らかな表面が得られるとしている.

長期の防食を考える場合は, 塗装との組合せを利用 することになるが，一般に亜鉛およびアルミニウムの 溶射層は多孔質であるため, 下塗りとしてのプライマ 塗装が必要であり，その上へクロム酸互鉛系の塗料を 中塗りし，最終仕上げに合成樹脂系の塗料を用いるの がよいとされる。亜鉛溶射被膜に適する塗装仕様とし ては, ポリビニルブチラール・ジンククロメート系の エッチングプライマの下塗り, ジンククロメート系中 塗り塗料ときり油変性フェノール樹脂の上塗り例や, りえ片状酸化鉄塗料やウレタン塗料, アルミ顔料入り ビニル塗料などが適しているという報告もある。いず れにしても, 溶射被膜に塗装する場合には, 下塗り拉 よび中塗りの塗装仕様がきめ手になる.

金属以外の溶射材料としてプラステックがあり, ビ ニル，ポリウレタン，エポキシなどの溶射被覆例もあ る.

\section{$3 \cdot 4$ 施工例について}

（1）石油および天然ガス掘削用プラットフォーム 北欧の北海開発計画に関連して，米国で製作した天 然ガスの探查用海洋プラットフォームの例では, 脚部 の防食に塗装と流電陽極法を採用している. 使用した 塗料はタールェポキシ・コーティング, 陽極にはアル ミニウム合金を用い25年間耐久性をもたせるといら設 計になっている.

北米ルイジアナ沖合に建設された 482 の油井ジャケ ットと 34 のプラットフォームの例では, $0.45 \mathrm{Hg}$, $0.045 \mathrm{Zn}$, 残りは99. 9\%の純Al合金の陽極を用いて陰 極防食を行い, 電流密度のコントロールは 50〜1500 $\mathrm{A} / 0.0929 \mathrm{~m}^{2}$ の範囲が可能になっている.

我が国で建造された海底油田掘削装置オーシャンプ ロスペクタの例では, 外板和よびタンクの合計 53000 
$\mathrm{m}^{2}$ に流電陽極方式を採用（陽極の総重量は 85 トン）

し, タールエポキシ塗料执よびフロートコートを併用 している.

（2）港湾施設和よびタンク

九州大分海岸工業地带に新しく鉄鉱石積卸海岸シー バースが建設された。ここでは 25 万トンの専用運搬船 4 隻が停泊できるような大規模な施設で，主バースは 長さ $620 \mathrm{~m}$, 幅 $450 \mathrm{~m}$, 平均水深 $30 \mathrm{~m}$ である.ここには 740 本の鋼管ぐい $(1 \sim 1.5 \mathrm{m \phi})$ が用いられているが, 水面下には 3541 個 のアルミニウム合金陽極を使用し， 12000 アンペアの防護電流が与えられるようになって いる.

サンフランシスコとオークランド間の世界最長の水 中輸送トンネルの例では, 外部電源による陰極防食法 を採用しているが，近くの他の構造物に電気的な影響 を与えている技それがあるので調査したところ，陽極 の外側約 $150 \mathrm{~m}$ では電位差はゼロで影響がないとの結 論を得ている.

U S スチール社は，埋設用鋼製貯蔵タンクの外面に 石灰バックフィル防食法を開発した. この方法は, 従 来の陰極防食法を改良したもので，タンクの周囲に石 灰を和き，石灰中の重炭酸カルシウムが陰極反応で生 ずる水酸イオンと反応し, タンク上に不溶性炭酸カル シウムを析出し，保護すべき鋼表面を減少するととも に, 陰極防食に必要な電流密度も減少することができ るといらものである.

\section{(3) パイプライン}

水中パイプラインは, 当初は浅海であったが最近は 深海で長く大口径となり，布設工法についてもたるみ と曲げ応力などむずかしい問題が多い. したがって， 腐食環境としてはあまりよくないため, 通常は陰極防 食や塗装が施工される。

電気防食は, 外部電源法, 流電陽極法の両法が利用 されているが, 前者は保守が必要なため長いパイプラ インには不向きである. 流電陽極法の場合, 陽極材料 には船舶の場合と同様最初マグネシウムが用いられた が，その後亜鉛またはアルミニウム合金にかわってい る. 設計する場合には, 埋設部あるいは海底での環境 条件 (流速, 土壤の比抵抗) をよく確かめる必要があ る. 比抵抗が $10 \sim 20 \Omega \mathrm{cm}$ で土の腐食性が強い場合 は, パイプラインに溶融アスファルトコーティングが 有効であるといわれている.

北海に㐨けるフィリップスグループの海底パイプラ インの電気防食の例では, $86.4 \mathrm{~cm}$ фの管の周囲に大 きな腕環状の陽極（幅 $30.5 \mathrm{~cm}$, 厚さ $6.4 \mathrm{~cm}$, 重量 $374 \mathrm{~kg}$ )を取付け，220マイルのラインに 2930 個取付 けている.

埋設パイプラインの陰極防食では, 保守のため電位
のモニタリングをする必要があるが，省力化する方法 としてライン上に無人測定装置を設置し, ヘリコプタ 一で測定值を受信して記録するよらなことも行われ， 測定值はフルスケールの $2 \%$ 正確さで受信が可能で, 受信装置は 2 100～ 2500 ポンド，測定装置は 150～250 ポンドであるといわれる。

(4) 鉄筋コンクリート

コンクリート中の鉄笳の腐食は, コンクリートのか ぶり厚さと関係があるといわれているが，鉄筋の防食 についても各種の試みがなされている. その中で鉄筇 の被覆に関するものをあげると, 金属被覆では亜鉛, ニッケル, カドミウム, 銅, 鉛, すずなどの被覆の比 較試験では, カドミウムの被覆がよいとの結論がださ れているが，高価であるため亜鉛めっきやタール系塗 料の塗装との組合せが実用的である.

このほかに，有機質の被覆材料としてはエポキシ樹 脂があり，有機質の被覆であっても鉄筋表面とコンク リートの付着性を妨害しないといわれている.

コンクリート中の鉄筋の腐食と防食については, 日 本材料学会腐食防食部門委員会, P C 構造研究委員会, コンクリート混和剤研究委員会で合同委員会を開催し (昭和51年 1 月), 討論されているのでその資料を参考 にされたい.

\section{参 考 文 献}

1) Hickether, C., Deut Farben-Z, 22, 106 (1968).

2) Ship \& Boat, 21, 21 (1968).

3) ВАПАПАЕВ, Г. А., Пром Строител, 44, 12 (1967).

4) Skipsteknikk, 6, 62; 65 (1968).

5) Tuthill, A. H., and C. M. Schillmoller, 防食技術, 16, 33 (1967).

6) Matthewman, W., and W.E. Heaton, Corrosion Sci., 8, 453 (1968).

7) Roots, D. C., Metal Finishing J. (London), 19, 200 (1973)

8) Crowley, J., Paint Varnish Prod., 61, 35 (1971).

9) Skarrebo, K., Western Paint Rev., 55, 14 (1969).

10) Shipping World Shipbuilder, 165, 99 (1972).

11) Mock, J.A., Mater. Eng., 71, 60 (1970).

12) Birkenhead, T.F., Shipbldg. Shipping Rec., 114, 18 (1969).

13) Bryn, T., Skipsteknikk, 11, 240 (1973).

14）森 稔, 柳瀬元昭, 豊田 信, 関西造船協誌, 151, 25 (1974).

15) Ginsberg, T., and J. J. Stevens, Paint Varnish Prod., 64, 19 (1974).

16) Kubitza, W., Hansa, 108, 256 (1971).

17) Cauwenberghe, C. Van, Peintures Pigments Vernis, 49, 446 (1973). 
18) Dick, R. J., Paint Varnish Prod., 60, 35 (1970).

19) Londen, A. M., J. Paint Technol., 42, 511 (1970).

20) Barth, C.D., Seewirtschaft, 2, 682 (1970).

21）森 稔, 川崎技報, 35, 49 (1969).

22) Court, F. H., and H. J. Vries, J. Oil Colour Chemists Assoc., 56, 388 (1973).

23) Pischky, H., Schiff Hafen, 24, 197 (1972).

24) Freiberger, A., and H. Horbund, Nav. Engrs. J., 81, 105 (1969).

25) Jones, D. F., Conf. Papers Intern. Oceanol. Conf. 2nd Brighton Engl., 471 (nd).

26) Devoluy, R., Marine Eng. Log., 75, 33 (1970).

27) Brun, J., Skipsteknikk, 10, 32 (1972).

28) 加藤復雄, 大沢一夫, 船の科学, 24, 67 (1971).

29) 船の科学, 23, 123 (1970).

30) 高木 勇, 造船技術, 1, 76 (1968).

31) Hartland, P., Skipsteknikk, 9, 344 (1971).

32) Terveer, D. J., Skipsteknikk, 11, 516 (1973).

33) Rogers, J., Trans. Inst. Marine Engrs., 83, 139 (1971).

34) Paint Varnish Prod., 59, 54 (1969).

35) McCoy, J.E., Trans. Inst. Marine Engrs., 82, 210 (1970).

36) Mater. Protect Performance, 12, 18 (1973).

37) Kurr, G. W., Proc. NACE Conf. 25th, 444 (1969).

38) Birnbaum, L.S., B. M. Taylor, and W. M. Strasburg, Jr., Nav. Engrs., 83, 13 (1971).

39）玉利昭一，造船技術，3，61 (1970).

40）鎌原正夫, 船舶， 41，102（1968）.

41）鎌原正夫, 船舶, 41，95 (1968).

42) Routley, A.F., Paint Technol., 31, 28 (1967).

43) Brown, P., Metal' Finishing, 66, 66 (1968).

44) 豊田 信, 森 稔, 造船工業, 3, 13 (1971).

45）松永昭介，造船技術，2，44（1969）.

46) Marine Eng. Log., 75, 57 (1970).

47) 落合正美, 塗装と塗料, 133， 45 (1966).

48) Coudenhove-Kalergi, J., Plastverarbeiter, 20, 407 (1969).

49) Klaas, H., Schiffbautechnik, 17, 21 (1967).

50）造船技術， 3，110（1970）。

51) Chromy, L, J. Kukla, and E. Smieszek, Plaste Kautschuk, 19, 135 (1972).

52) Can Paint Finishing, 42, 38 (1968).

53) Smith, A. L., Conf. 2nd Brighton Engl., 459 (nd).

54) Hutchins, J. S., and M. Mckenzie, PB Report 220313, 29 (1973)

55）森本隆也, 金属材料, 10, 61 (1970).

56）たとえは長大構造物塗装第一次報告, 防錆管理, 14, 13 (1970).

57）たとえば，長大構造物塗装第二次報告，防錆管理， 15, 11 (1971)

58）森 芳徳，土木技術資，13，13 (1971).
59）森 芳徳，西島高秀，土木技術資，13，393 (1971).

60）佐藤 靖, 吉田真一, 橋本達知, 大里敏夫, 今井文夫, 菅谷ひろし，鉄道技研報， 771，1 (1971).

61) Meyer, G., Deut Farbenz, 20, 526 (1966).

62) Newnham, H.A., Shipbuilding \& Shipping Record, 109, 301 (1967).

63) Am. Paint J., 156, 565 (1969).

64) Surface Coatings, 4, 108 (1968).

65) Cupr, V., and B.Cibulka, Deut Farben-Z, 21, 494 (1969).

66) Langenhaeck, J. C., Peintures Pigments Vernis, 46, 625 (1970).

67）福井三郎, 山本正登, 松村雄介, 三菱重工技報, 9, 257 (1972).

68）石川信雄, 防錆管理, 17, 11 (1973).

69）浦部匡司, 防錆管理, 17, 17 (1973).

70) 島田喜十郎, 森稔, 村田安房, 浦部匡司, 橋梁と基 礎, 5, 38 (1971).

71）浅間達雄, 山住幸光, 橋梁, 6, 40 (1970).

72) 中山雅道, 橋本定明, 塗料の研究, 88, 7 (1974).

73）防錆管理, 15, 21 (1971).

74) Nauman, F. K., and F. Spies, Prakt Metallog., 10, 588 (1973).

75) Rademacher, C. H., Stahlbau, 42, 161 (1973).

76) Swan, J.D., Preprints Ann. Offshore Technol. Conf. 2nd, 2, II. 223 (1970).

77）東田信安，内川千彦，富士鉄技報， 18，15（1970）。

78）根来広平，石黒隆義，富士鉄技報， 18，28（1970）。

79）鉄鋼界, 21, 63 (1971).

80）尾家義弘，山田光二，武野 優，富士鉄技報， 18，60 (1970).

81) Bolwell, A. J., Design News, 25, 42 (1970).

82) Eijnsbergen, J. F. H., Europe Ind. Rev., 3, 11, (1970).

83) Hall, J. R., Corrosion Prevent Control., 17, 12 (1970).

84) Prat Soudage, 24, 34 (1970).

85) Wuich, W., Metalloberflacche, 23, 244 (1969).

86) Tech. Betrieb, 23, 267 (1971).

87) Birkemoe, P. C., and D. C. Herrschaft, Civil Eng., 40, 42 (1970).

88）鈴木久男，土木技術，22，34（1967）.

89) Jenrich, E., Bauplan-Bautech, 25, 219 (1971).

90) Davidson, S. F., and J. L. Norris, Civil Eng., 38, 33 (1968).

91) Roads Streets, 113, 46 (1970).

92) Ellinger, M. L., Paint Mf, 43, 7/8, 32 (1973).

93) Mayne, J. E. O., Brit. Corrosion J., 5, 106 (1970).

94) Kunstoffe Bau, 28, 41 (1972).

95) Hochweber, M., Deut Farben-Z, 24, 182 (1970).

96) Gönnel, F., Haus Tech. Vortragsveroeffentl, 297, 12 (1972). 
97) Dear, H., Metals Eng. Quart., 13, 41 (1973).

98) Richardson, M.R., Preprints Ann. Offshore Technol. Conf. 2nd, 2, 497 (1970).

99）長崎作治，土木技術， 24，68 (1969).

100) Creamer, E. V., Preprints Ann. Offshore Technol. Conf. 2nd, 2, 485 (1970).

101) Can Paint Finishing, 47, 22 (1973).

102) Brouillette, C. V., Mater. Protect, 9, 19 (1970).

103）金属材料, 10, 82 (1970).

104）森稔, 金属材料, 10, 27 (1970).

105) Lehmann, J. A , J. Metals, 22, 56 (1970).

106) Ferry, C. R., Proc. NACE Conf. 24th, 119 (1968).

107) Byrne, P. B., Mater. Protect Performance, 10, 21 (1971).

108) Röbke, H., Seewirtschaft, 5, 847 (1973).

109) Grandstaff, C. M., and H. L. Craig, Jr., Mater. Protect Performance, 10, 29 (1971).

110) Morgan, J. H., Brit. Corrosion J., 5, 237 (1970).

111) Metals Mater., 5, 150 (1971).

112）花田政男, 防食技術, 19, 12 (1970).

113) Nekoksa, G., and C.S. Potosnak, Preprints Ann. Offshore Technol. Conf. 2nd, 2, 465 (1970).

114) Davis, J.G., G. L. Doremus, and F.W. Graham, J Petrol. Technol., 24, 323 (1972).

115）筧 建彦, 大内一憲, 遊佐 功, 防食技術, 21, 124 (1972).

116) Hudgins, C. M., Jr., B. M. Casada, R. L. Schroeder, and C.C. Patton, Preprints Ann. Offshore Technol. Conf. 2nd, 2, II-257 (1970).

117) Lennox, T. J., Jr., and M.H. Peterson, PB Report 195314, 30 (1971).

118) Lennox, T. J., and M.H. Peterson, Mater. Protect Performance, 10, 31 (1971).

119) Peterson, M.H., T. J. Lennox, Jr., and R.E. Groover, Mater. Protect, 9, 23 (1970).

120) Vreeland, D.C., and G. T. Bedford, Mater. Protect, 9, 31 (1970).

121) Lennox, T. J., Jr., and M. H. Peterson, PB Report 204406, 24 (1971).

122) Peterson, M.H., T. J. Lennox, and R.E. Groover, Proc. NACE Conf. 25th, 314 (1969).

123）藤井政夫, 佐伯庄吾, 熊田 誠, 日本金属学会誌, 34, 534 (1970).

124）小林豊治, 金属材料, 10, 25 (1970).

125) Backstrom, T. E., and F. E. Causey, PB Report
184734, 23 (1969).

126) Wuich, W., Werkstaat Betreieb, 103, 871 (1970).

127）栖原寿郎, 福田重久, 鋳鍛造, 23, 19 (1970).

128）田中 清, 金属材料, 11, 51 (1971).

129）栖原寿郎, 福田重久, 金属, 40, 50 (1970).

130) Reininger, H., Metall., 22, 795 (1968).

131) Welding J., 46, 519 (1967).

132) Welding J., 49, 931 (1970).

133) Welding J., 49, 657 (1970).

134) Goh1, K., Schweisstechnik, 19, 86 (1969).

135）橋本定明, 実務表面技術，236， 459 (1973).

136) Radtka, S. F., Paint Varnish Prod., 63, 29 (1973).

137) Claxton, A. E., and E. V. Carter, Brit. Corrosion J., 4, 187 (1969).

138) Legrand, J., Corrosion Traitement Protect Finition, 18, 301 (1970).

139) Europe Oil, 7, 36 (1968).

140) Doremus, E.P., and R.B.Pass, Proc. NACE Conf. 25th, 455 (1969).

141）黑瀬博志, 池田やす夫, 海洋開発, 3, 59 (1970).

142) Nakagawa, M., Conf. Paper Intern. Oceanol. Conf. 2nd Brighton Engl., 167 (nd).

143) Bomar, H.E., and R. H. Marchand, Mater. Protect, 9, 19 (1970).

144) Vrable, J. B., Mater. Protect Performance, 12, 44 (1973).

145) Small, S. W., Conf. Preprints Am. Soc. C1v11 Engrs., 1974, 22 (1973).

146）早川武夫, 秋浜成友, 海洋開発， 3，64（1970）。

147) Mackay, W. B, and A. T.G. Edmonds, Corrosion Prevent Control, 20, 6 (1973).

148) Anti-Corrosion Methods Mater., 14, 15 (1967).

149) Liesche, H., Bauplan-Bautech, 26, 32 (1972).

150) Davis, J. A., Petrol Petrochem. Intern., 13, 70 (1973).

151) Process Eng., Sept., 115 (1973).

152) Duffaut, P., L. Duhoux, and B. Heuze, Ann. Inst. Tech. Batiment Trav. Publics, 305, 101 (1973).

153) Bird, C. E., and F. J. Strauss, Mater. Protect, 6, 48 (1967).

154) Trivella, L., Verniciature Decorazioni, 1, 25 (1972).

155) Rinaldi, G., Proc. Intern. Navigation Congr. 22nd, Paris Sect. 2, Subj. 5, 63 (1969).

156）日本材料学会腐食防食部門委員会資料， 14，74，Part 1 (1976). 